\title{
QUATERNARY FANS AND COLLUVIUM AS INDICATORS OF ENVIRONMENTAL CHANGE AND LANDSCAPE SENSITIVITY
}

\author{
Michael F. THOMAS
}

\begin{abstract}
Unconsolidated sediments in the humid tropics range from highly altered weathering products involved in minimum, low energy transport, to coarse fans and landslide deposits. But most can be regarded as colluvium and alluvium showing imprints of episodic sedimentation. These deposits may span the entire Cenozoic, but 14C dating has led to a focus on Late Quaternary sediments. Many studies have indicated concentration of activity between the Last Glacial Maximum (LGM) and the early Holocene 'pluvial', but recent use of Optically Stimulated Luminescence (OSL) dating indicates episodic sedimentation throughout the Last Glacial Cycle in some landscapes. The low resolution of most OSL studies limits attempts to construct true event stratigraphies. But, despite this restriction, these sediments record the detailed history of landscape sensitivity to environmental change, and this history includes the effects of continuing weathering and pedogenesis. Bringing together studies of weathering, landscape sensitivity to environmental change, and source-to-sink models of sedimentation, provides a conceptual framework to understand earth surface systems within a Quaternary time frame.
\end{abstract}

Keywords: Colluvium, fans, landscape sensitivity, Quaternary sediments, sediment sources.

\section{INTRODUCTION}

Unconsolidated sediments blanket large parts of the tropics. They include Tertiary deposits such as the Barreiras Formation of Brazil, the Continental Terminal and Bullom Series sediments in West Africa, and the Kalahari Sands of central and southern Africa. Such formations are particularly associated with Cenozoic denudation and the sedimentary history of tropical cratons, and the sediments are frequently classified as fluviatile, lacustrine, aeolian or marine facies deposited at the margins of the land mass or in intra-cratonic basins. In the humid tropics, the sediments are characteristically derived from ferrallitic (lateritic, bauxitic) weathering profiles often of Mesozoic age, by erosion under conditions of low relief. These source materials, and the mainly low energy conditions of transport, produce sediments ranging typically from sands to 'lateritic' clays. Their advanced weathering ensures a paucity of carbonates and sulphates that form common cementing materials in other environments. Silica cementation is also rare in humid environments, though common across Australia and southern Africa. On the other hand, Fe cementation, forming varieties of ferricrete and enrichment by $\mathrm{Al}$, due to further weathering is common. Such sediments may be particularly sensitive to erosion following perturbations in the environment, arising from whatever cause. In fact, one of the problems of interpretation that they pose is a history of repeated mobilisation and redeposition, often involving only minimum distances of transport. Another, is the effect of continued weathering of the sediments following deposition, which can obscure original sedimentary structures.

This style of sedimentation can be considered part of a 'cratonic regime' (FAIRBRIDGE \& FINKL 1980), embracing prolonged periods of weathering followed by shorter episodes of stripping of the saprolite mantle. ERHART (1955) and MILLOT (1964/1970) anticipated these ideas, and the former's concepts of biostasie and rhexistasie have passed into the vocabulary of geo-ecology. However, our understanding of these sedimentary environments and their modern analogues is limited. FAIRBRIDGE \& FINKL (1980) envisaged very long timescales for these events: $10^{7}-10^{8} \mathrm{y}$ for cratonic stability and weathering; $10^{4}-10^{5} \mathrm{y}$ for episodes of tectonic or climatic crisis and erosion. 
But more detailed studies have shown that events on shorter timescales involving Quaternary climatic oscillations over $10^{2}-10^{4} \mathrm{y}$ also need to be considered within this approach (THOMAS \& THORP 1985).

Many of the Cenozoic sequences are capped by 10-20 m of apparently structureless sediment, such as the yellow-brown Belterra Clay in the Amazon Basin (TRUCKENBRODT et al. 1991), and there are similar materials capping weathering profiles in Kalimantan (Indonesia) (Figure 1). In West Africa, the Continental Terminal also displays unsorted lateritic sediments, which are probably in part a result of the local redistribution of duricrusted profiles (MOSS 1965). A possibly comparable phenomenon is seen in the 'white sands' of podzolising environments. These materials can be 3-5 m thick and are apparently homogenous. They are typical of profiles developed on coastal plain alluvial terraces, but they can be found on friable sandstones within the perhumid tropics. Accounts of all these materials describe similar groups of processes as responsible for their formation. They divide between in situ transformation of parent sediments by leaching and chelation processes (CHAUVEL 1977,
CHAUVEL et al. 1987, BRABANT 1987, LUCAS et al. 1988, TRUCKENBRODT et al. 1991, THOMAS et al. 1999) and colluvial or alluvial translocation by flowing water (HEYLIGERS 1963, MOSS 1965, AB'SÁBER 1982). The action of termites has also been invoked (TRUCKENBRODT et al. 1991).

Outside the present-day tropics, possibly homologous sediments include the 'argiles plastiques' of the Paris and Aquitaine Basins of France (MILLOT 1964, BLANC-VALLERON \& THIRY 1997) overlying the Upper Cretaceous limestones (chalk). These materials are often regarded as 'remanié' sediments, following dissolution of impure limestones containing clay. Where evidence for conventional fluvial transport is lacking, the processes thought to account for such deposits divide into, those requiring dissolution of rocks with the collapse of weathering profiles, and local redistribution of weathering products by ill-defined processes of ‘colluviation'. Where clastic transport can be demonstrated, it has often been localised within alluvial fan environments. Of course, the larger river basins contain alluvial plains and terraces, which are not the main subjects of this enquiry.

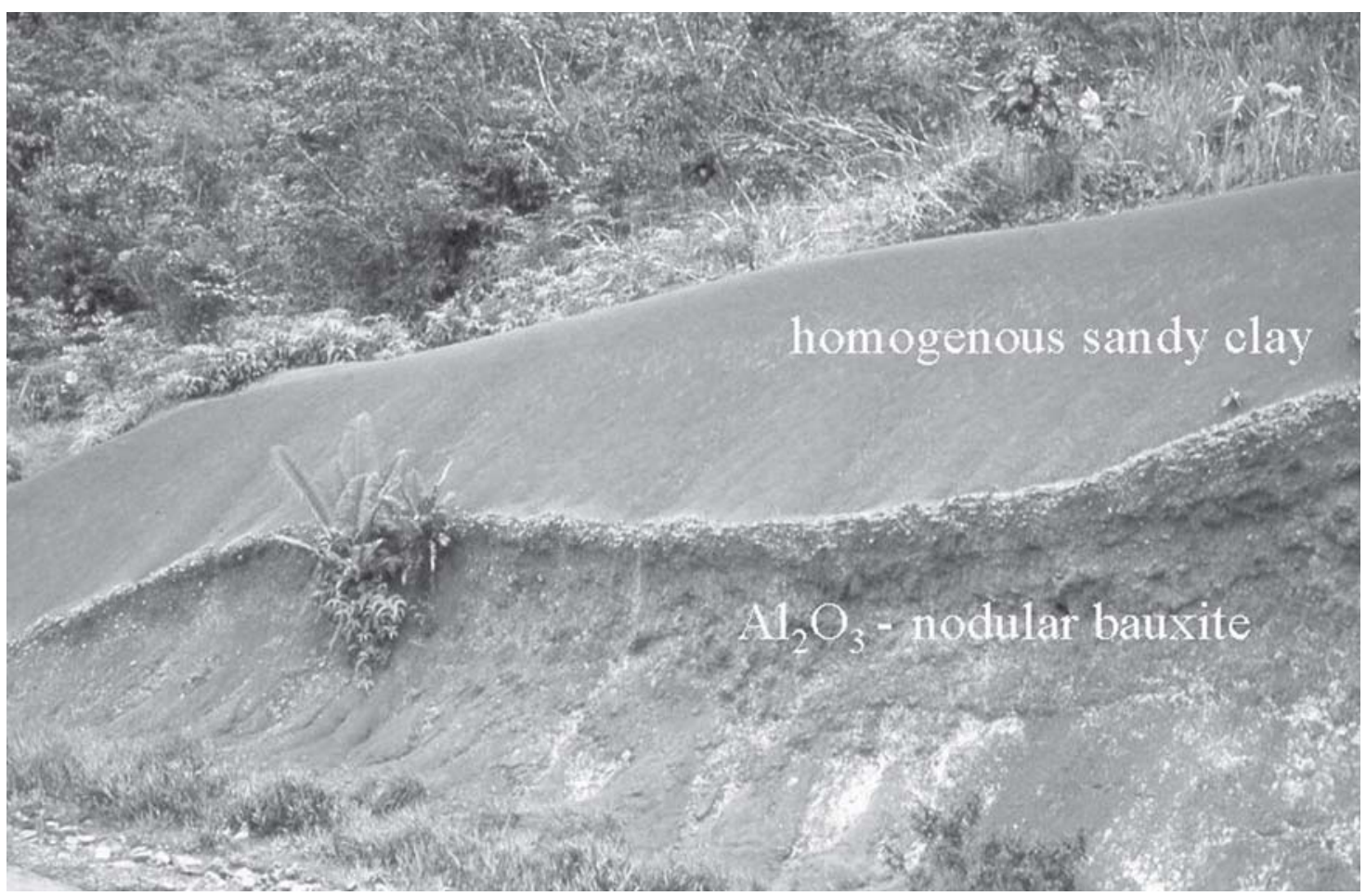

Figure 1 - Section through weathered igneous rocks in NW Kalimantan. Gibbsitic profiles predominate in this lowland equatorial environment of multi-convex ("meias laranjas") hills. The nodular gibbsite (bauxite) forms a concentrated horizon, above which structureless, yellow-brown sandy clay attains a thickness of several metres. 


\section{PEDOGENIC AND GEOMORPHIC EVOLUTION}

\subsection{Profile evolution and collapse}

Work in NW Kalimantan has established the presence of late Pleistocene alluvial terraces and Holocene beach barriers (THORP et al. 1990), both of which carry podzolised white sand profiles. Examination of gibbsite-rich weathering profiles over granodiorite in the same area has indicated the possibility of lateral eluviation, and possibly dissolution of kaolinite, with the formation of residual white sands along the margins of river valleys (THOMAS et al. 1999). In the Rio Negro basin, a similar juxtaposition of ferrallitic and podzolic residues is seen by BOULET et al. (1997), and by DUBROEUCQ \& VOLKOFF (1998), as an illustration of the transformation of ferrallitic soils into podzols by pedogenic processes, a theory anticipated by CHAUVEL (1977) and discussed by DUBROEUCQ \& BLANCANEAUX (1987).

However, the story does not end with 'soil transformation systems’ (BOULET et al. 1997), because the white sands, which appear to have been formed by both chemical and mechanical eluviation (vertical or lateral) in profile, have also become entrained into the fluvial system by detachment of quartz grains. All stages in weathering profile evolution, mechanical and chemical eluviation of clays and the colluvial and alluvial transfer of sandy sediment are, therefore, involved. In the absence of abrupt environmental perturbation these processes may be quasi-continuous and lead to structureless sediments and a lack of erosional unconformities.

\subsection{Erosion and depositional episodes}

By contrast, there is ample evidence for punctuated or episodic erosional/ depositional events from humid tropical landscapes. The same 'white sands' discussed above have also been considered as indicators of environmental change and redistribution of saprolite mantles (HEYLIGERS 1963, AB'SÁBER 1982, FAIRBRIDGE \& FINKL 1984). Wherever slopes are sensitive to environmental perturbation, abrupt changes to the geomorphological system are recorded in widespread landslides and fan deposits, which are clearly demarcated in the terrain. The importance of late Quaternary landslide events has been demonstrated from eastern Brazil (MODENESI 1983, 1988; MODENESI-GAUTTIERI 2000), and they are evident from most tropical areas, wherever there are steep slopes. Few such events have been dated, but MODENESI-GAUTTIERI(2000) found 3 major phases of deposition on the slopes of the Campos do Jordão Plateau: 37-31 ka BP, 22-14 ka BP, 9-8.5 ka BP. It is significant that the author noted that this evidence for episodic landscape instability conflicts with suggestions of continuous cool-dry conditions persisting from 35-10 ka BP, based on pollen evidence cited by BEHLING (1997). Alluvial fans are also common along escarpment fronts, but again few have been securely dated. The paucity of dates for these environments reflects the problems of sampling very coarse sediments and, often, the lack of suitable organic material for radiocarbon dating.

Much of the colluvium draping the lower slopes of hills in the humid tropics cannot be described as either landslide debris or alluvial fan sediment. It is more diffuse, having its origins on neighbouring hillslopes and directly connecting to these. However, it is not structureless, but reveals a complex stratigraphy. Pioneer work at Bananal in SE Brazil has provided a type locality for this type of sediment (DE MEIS et al. 1984; MOURA et al. 1989), and the term 'rampa complex' was introduced to describe the characteristic combination of erosional scars (hillslope hollows) and colluvial/alluvial aprons found in this area (DE MEIS \& MACHADO 1978). In Africa, the French term 'glacis' has been used to describe similar forms (MICHEL 1973). COELHO NETTO (1999) has recently collated a remarkable set of radiocarbon dates for the deposits in SE Brazil and demonstrated a concentration of ages around $10 \mathrm{ka} \mathrm{BP}\left({ }^{14} \mathrm{C}\right)(11.2 \mathrm{cal}$. $\mathrm{k} \mathrm{yr} \mathrm{BP})$, with a few dates around the Last Glacial Maximum (LGM) but hardly any dates between $9 \mathrm{ka}$ and $1 \mathrm{ka} \mathrm{BP}\left({ }^{14} \mathrm{C}\right)$ (10-1 cal. $\mathrm{k}$ yr BP). This is strong evidence for landscape instability and sediment mobility during the unstable, changing climates at the end of the Pleistocene. In some of the main river valleys of SE Brazil, copious sedimentation also occurred during this period (DE MEIS \& MONTEIRO 1979), and a few dates indicate that this material is late Pleistocene. The detailed stratigraphy of these deposits indicates that many episodes of deposition were involved, and laminated sediments in certain valleys (see THOMAS 1994, Figure 8.12) suggest that some sediment was supplied in pulses, due either to many individual storm events, or to a strongly seasonal flux. The possible influence of neotectonics on slope and stream sedimentation in this area of SE Brazil is acknowledged by MODENESI-GAUTTIERI (2000), but how tectonic events interacted with the impacts of climate change on slope stability and catchment processes remains poorly understood. 


\section{LATE QUATERNARY SEDIMENTATION}

Most of these sediments are attributed to the Late Quaternary and have hitherto been dated by radiocarbon methods. But with the advent of thermoluminescence (TL) and OSL methods for dating quartz grains, many deposits that could not be dated by radiocarbon methods can now be analysed. Moreover, the actual sedimentation and burial of sand grains in the deposit can now be directly dated.

In a recent study of alluvial fans fronting the main escarpment of the tablelands in the rainforest zone of NE Queensland (THOMAS et al. 2001; NOTT et al. 2001), it was established (using TL and Accelerator Mass Spectrometry -AMS $-{ }^{14} \mathrm{C}$ dating techniques) that the main period of formation was during the LGM, from > $27 \mathrm{ka} \mathrm{BP}$ to ca. $15 \mathrm{ka} \mathrm{BP}$, after which the fans became incised by linear streams. This study has also raised a question concerning the relationship of the alluvial fans, which are predominantly fine-grained, to landslide lobes and occasional coarse debris cones that occur in the same area. Conditions for the formation of the alluvial fans were probably reduced rainfall (possibly to $800 \mathrm{~mm} \mathrm{y}^{-1}$ at the LGM, a reduction of 64\%) and vegetation cover (KERSHAW 1978, MOSS \& KERSHAW 2000). Loss of runoff and stream power, accompanied by higher sediment yields, appear to have been the factors leading to rapid deposition of sediment in this area. More humid conditions may have been responsible for the landslides, but these remain the subject of ongoing investigation. The advanced weathering of source-area metamorphic rocks, along the lower slopes of the escarpment has controlled the sediment type and also led to many small fans being derived from the escarpment front.

Luminescence techniques also extend the timescale of investigations well beyond the limits of radiocarbon dating (ca. $40 \mathrm{k}$ yr BP), and this has already offered fresh insights into the evolution of landscapes during the Quaternary. Illustration of this has recently come from work in central Africa. In Eastern Zambia, around the town of Chipata, in a savanna woodland environment $\left(\mathrm{P}=1100 \mathrm{~mm} \mathrm{y}^{-1}\right)$ near the border with Malawi, a group of prominent landslides occur around residual hill masses comprised of weathered granulite and quartzite. On the basis of evidence for the grouping of landslide events in other areas at times when the climate was thought to be wetter, around the PleistoceneHolocene transition and in the early Holocene humid period (post $11 \mathrm{cal} \mathrm{k} \mathrm{yr} \mathrm{BP)} \mathrm{(SHRODER} \mathrm{1976,}$ RENEAU et al. 1986, THOMAS 1998), it was speculated (THOMAS, 1999), that these features, which are very fresh in the landscape, might date from the terminal Pleistocene or early Holocene. However, subsequent dating of intercalated alluvial sediments at one landslide site, using OSL methods, has shown that at least some of these events took place before $200 \mathrm{k}$ yr BP (THOMAS \& MURRAY 2001). If all similar slides in this area are of comparable age, then the landscape experienced a major crisis before the Last Glacial Cycle, and slope failure on this scale has not been repeated since. The landslides involved deep-seated failures in the weathered granulite (schist) and the residual forms and debris lobes have experienced very little modification since that time.

Alluvial fans and colluvium are also found in this field area, and are widespread in the savanna environments of eastern and southern Africa (WATSON et al.1983, GOUDIE \& BULL 1984, MEADOWS 1983, 1985, ERIKSSON et al. 1999; SØRENSEN et al. 2001; THOMAS 1994, 1999; THOMAS and MURRAY 2001) and in the forested areas of central Africa (RUNGE 1992, 1996, 2001). But few recorded sequences have been securely dated. ERIKSSON et al. (1999) indicated two colluvial episodes in central Tanzania, one from $14.5-11.4 \mathrm{k} \mathrm{yr}$ (OSL) and the other post $1 \mathrm{k}$ yr (OSL). On the Nyika Plateau in Malawi, MEADOWS $(1983,1985)$ recorded a period of rapid stream sedimentation in small dambo valleys, commencing in $12 \mathrm{k} \mathrm{yr} \mathrm{BP}\left({ }^{14} \mathrm{C}\right)(14 \mathrm{cal} . \mathrm{k} \mathrm{yr}$ BP) and continuing for $7 \mathrm{kyr}$, while SHRODER (1976) obtained a date of $10.2 \mathrm{k} \mathrm{yr} \mathrm{BP}\left({ }^{14} \mathrm{C}\right)(11.4 \mathrm{cal} \mathrm{k} \mathrm{yr} \mathrm{BP})$ from a sample buried by a landslide in the same area. Late Quaternary colluvium has been identified from many other parts of the tropics including the NW Deccan in India (JOSHI \& KALE 1997).

Two recent OSL dating projects in central Africa have, however, demonstrated that not all colluvial deposits date from this concentrated period at or following the end of the Pleistocene. In the Chipata area of Zambia, previously discussed, a series of fans and broad sheets of colluvium extend for up to $1 \mathrm{~km}$ from the base of the hillslopes towards the river valleys, sloping at $2-5^{\circ}$. Gullying has exposed one $4.8 \mathrm{~m}$ section through mainly sandy colluvium containing discontinuous thin beds of pebbles and cobbles. Sands sampled from this section range in age from $65 \mathrm{kyr}$ (OSL) (at $4.1 \mathrm{~m}$ ) to $9 \mathrm{kyr}$ (OSL) at $0.3 \mathrm{~m}$ (Figure 2). In another section two distinct sedimentary events dated to $45 \mathrm{k}$ yr (OSL) and $90 \mathrm{k}$ yr (OSL), and coarse basal sediments could be at least 100 ka in 


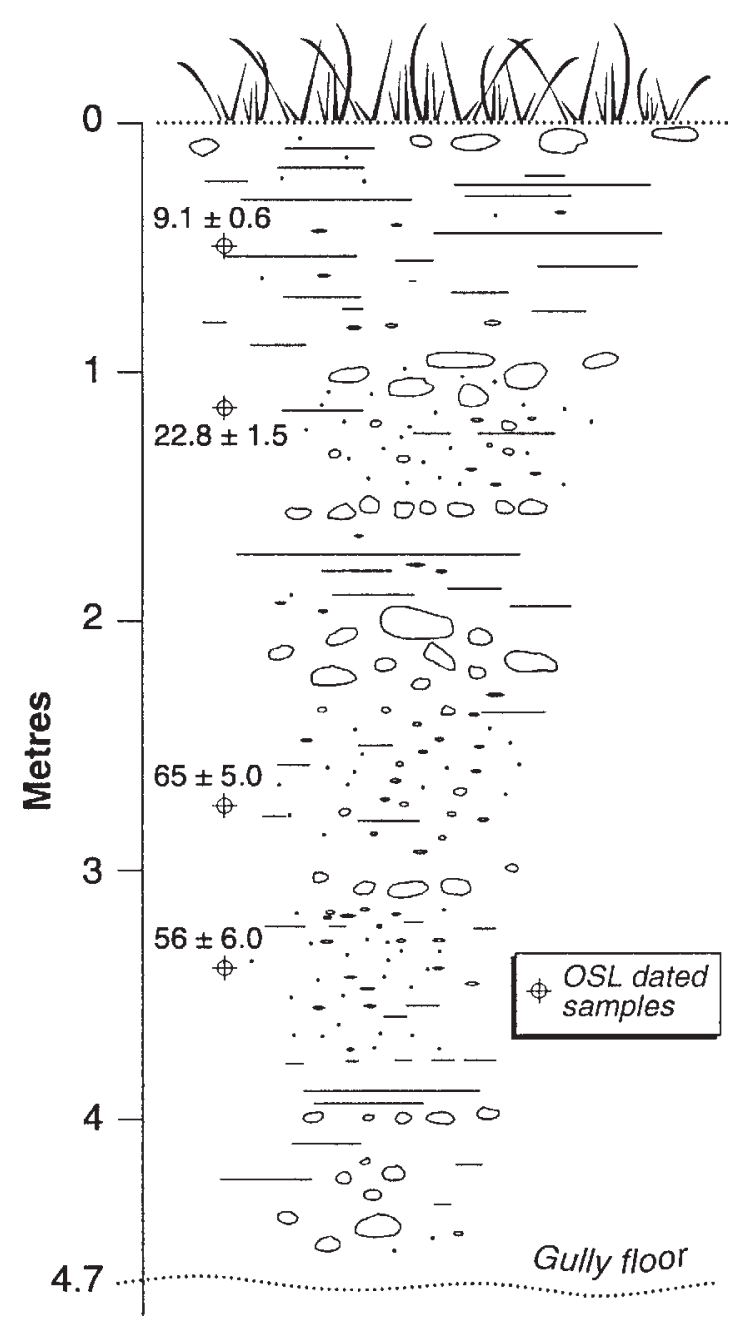

Figure 2 - Simplified diagram of gully section through colluvium in Eastern Zambia. OSL samples taken from sandy sediments with at least $30 \mathrm{~cm}$ separation from surface and from cobble-gravel beds. Rates of accumulation have been low but high-energy pulses have brought cobblesized clasts to the section intermittently. The landform resembles a low-angled fan or depositional 'glacis' extending $1 \mathrm{~km}$ from source hillslope (see Thomas \& Murray, 2001).

age (THOMAS et al. 2001). Comparable results were obtained in a similar environment, from a $12 \mathrm{~m}$ section in Morogoro District, Tanzania by SØRENSEN et al. (2001), but here the upper layers were Late Holocene in age (4.5-3.5 $\mathrm{k} \mathrm{yr}$, OSL).

These results demonstrate recurrent landscape instability throughout the Last Glacial Cycle (125 k yr). The alternative explanation, of a slow, incremental evolution of slopes lacking evidence for environmental crises is contradicted by the nature

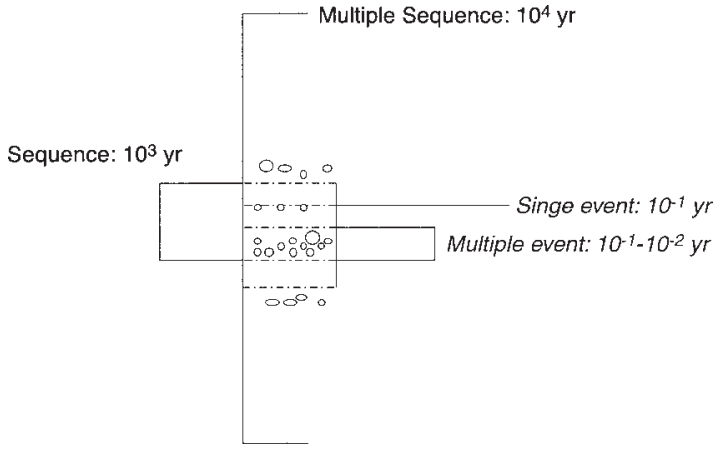

Figure 3 - Timescale relationships within colluvial sediments fed by (quasi-alluvial) wash processes. Single events may be traceable as single-clast gravels fining upward into sands, but defining these is difficult. Multiple (storm) events are more likely to lead to thicker gravels with discontinuous bedding. Dating with OSL is most likely to achieve $10^{3} \mathrm{yr}$ (millennial) resolution.

of the stratigraphy, in which cobble beds interrupt the accumulation of fine sandy sediment throughout the sequence. These allow the identification of single and multiple events and sequences, which at present we cannot date accurately (Figure 3). But there is no evidence from these deposits of a major sediment flux concentrated at the onset of the Holocene, nor is there a clear signal at these sites of increased sedimentation in the late Holocene, reflecting human occupation and land use. It should be stated, however, that a younger colluvium (undated) is found on some neighbouring slopes. Interpretation of these findings in palaeoenvironmental terms is difficult. The area in E Zambia lies at latitude 1340'S (long. 32 ${ }^{\circ} 40^{\prime} \mathrm{E}$ ), and it has been suggested by GASSE (2000) that, in Africa beyond $10^{\circ} \mathrm{S}$ latitude, the distinctive tropical rhythm of a cold, dry LGM followed by a rapid, if erratic, increase in rainfall, culminating in an early Holocene 'pluvial' was effectively reversed (wet LGM; dry early Holocene). Former water levels in nearby Lake Malawi have been dated and interpreted as showing a high stand at the LGM, falling subsequently (FINNEY \& JOHNSON 1991, SCHOLTZ \& FINNEY 1994).

It is tempting to suggest that pulses of sediment in this landscape represent the impacts of sudden warming (DANSGAARD-OESCHGER) events in the Quaternary record, but the low resolution of available dated sequences precludes such an analysis. It is, however, important to recognise that landscape 
activity in the Quaternary reaches far beyond the events of the last $22 \mathrm{k} \mathrm{yr}$., and with the availability of luminescence techniques for dating quartz grains we have a potential tool for understanding this longer history. In addition, the use of cosmogenic isotope dating of rock surfaces exposed by erosional events has the potential to add further to our understanding.

\section{DISCUSSION}

\subsection{Weathering and sediment sources}

The notion of an almost steady-state transformation of ferrallites into podzols under a humid tropical regime in a landscape of low relief and high watertables, without significant mechanical transfers of sediment, remains controversial. But, equally, the accumulation of sediments as a result of episodic erosion does not take place without the intervention of active weathering processes, and in the time available during a glacial-interglacial cycle (125 k yr) significant alteration of regolith mantles will occur (in both autochthonous and allochthonous materials). Some pedogenic changes produce major profile discontinuities, imitating erosional unconformities, while deep, homogeneous surface horizons may reach to depths of several metres (Figure 1).

The same factor also means that episodes of erosion and deposition spaced in time across $10^{4}$ $10^{6} \mathrm{yr}$, will derive sediment from re-weathering of source rocks. It is, therefore, mistaken to assume that the store of saprolite along scarp fronts or within residual hill masses is entirely inherited and static when viewed in relation to sediment generation. On the other hand, weathering profiles involved in deepseated landslides are likely to be inherited from the geological past, and renewed weathering following major slope failures will often be shallow in comparison. Thus many major landslides that occurred during the Pleistocene are found as relict features in the landscape and subsequent slope instability has often been superficial.

In the cases cited, the deep ferrallitic profiles in the granulites of eastern Zambia are associated with residual hills standing 200-300 m above an ancient planation surface (ca. $1200 \mathrm{~m}$ asl), and the regolith is probably early Tertiary or Cretaceous in age. Low rainfall (ca. $1100 \mathrm{~mm} \mathrm{y}^{-1}$ ) has almost certainly limited the potential for further weathering in this landscape. On the other hand, many of the fans in NE Queensland derive fine-grained sediment from the escarpment front (the source area is 200-400 m below any ancient planation surface), where weathering might be considered relatively recent and active within a wet (3000+ $\mathrm{mm} \mathrm{y}^{-1}$ ) monsoon (forest) climate.

The influence of sediment sources on the sedimentary record is not always considered fully in discussions of Quaternary history. The linkage between deep weathering profiles of advanced alteration and sediments derived by erosion of this mantle was recognised, long ago, by BAKKER (1957), in a paper that merits greater recognition than has been accorded to it. BAKKER worked in Surinam and noted that the juxtaposition of bare-rock inselbergs and zones of lateritic (ferrallitic) weathering meant that standard correlative techniques for understanding sedimentary sequences would not apply to these landscapes. But the nature of tropical saprolites and their commonly abrupt transitions to fresh rock has meant that sediment fluxes have been bi-modal: either fine grained quartz sands, silts and clays or very coarse rock fragments of cobble to boulder size, as seen in Zambia. TRICART (1959, TRICART \& CAILLEUX 1965) was one of many geomorphologists who viewed this situation in terms of the alternating weathered plains and rocky cataracts (sulas) found along the thalwegs of tropical rivers. But the implications are the same: many tropical landscapes contain large stores of highly weathered saprolite, even in terrains where there are many rocky outcrops. The saprolite may be Mesozoic in age or can be Quaternary, in either case it may remain stable under forest on slopes of $>20^{\circ}$. But it is sensitive to environmental perturbation, and can be redistributed across piedmont slopes over extended periods of time without change in facies.

4.2 Abrupt environmental change and landscape sensitivity

Most studies of Quaternary sediments have tried to answer the question: 'when did erosion and sedimentation take place', without considering carefully the nature and magnitude of the environmental changes necessary to bring about the observed chronology. In this regard geomorphologists are often seen as dependent on other proxy data, often from palynology, for evidence of climate and vegetation change. But most pollen cores come from mires and lake sediments, and both occupy low points in the landscape, whereas piedmont sedimentary covers are derived from upper hillslopes. Thus, when pollen spectra show continuity of woodland cover during climate 
changes, these forests may not have survived on drier sites in the landscape. KADOMURA (1995) has pointed out that forest-savanna mosaics or catenas may have resulted from the drying of late glacial climates and forest regression and fragmentation in tropical Africa. Such landscape patterns are not addressed by the interpretations of most available pollen records. Furthermore, it has been pointed out that hiatuses occur at many pollen sites at the time of the LGM (LEDRU et al. 1998), so that both temporal and spatial resolution based on this type of proxy data are much lower at critical times than is generally recognised. High-resolution data from ice-cores (such as GISP2) and marine sediments increasingly reveal the importance of short-term climate variability and the abrupt nature of climate change over periods of centuries (perhaps decades). Attaining a comparable resolution from land-based sediment records has proved elusive.

- The meaning of 'abrupt' environmental change

The importance of geomorphological evidence for the record of climate change lies mainly in the impact such changes have had on the visible landscape. Two issues can be focussed in this discussion. First, what do we mean by 'abrupt' climate change in the context of the Quaternary record? It can be argued that this concept is timescale dependent. When we consider the Last Glacial Cycle (100 k yr), then an abrupt change may have occurred over a period of $1 \mathrm{k} \mathrm{yr}$, but over the $10 \mathrm{k}$ yr of Holocene time we look for evidence of change over periods of $0.1 \mathrm{k}$ yr (centuries). This also applies to recorded changes, and abrupt change within a period $10 \mathrm{yr}$ may be envisaged as taking place within $0.01 \mathrm{yr}$ (days) (Figure 4). The implications of these perceptions for the understanding of process, using different timescales of enquiry are significant. High resolution studies, for example, invoke individual events to account for landscape change and sedimentation, and attempt to establish an 'event stratigraphy'. Over the longer timescales such an approach is usually impossible and periods of (relatively) rapid landscape change are identified that lead to accumulations of sediment. Such sedimentation will be punctuated or episodic, but we are often unable to place these events in a secure chronology. Unfortunately OSL dating cannot help, because for sediments $10 \mathrm{ka}$ in age the typical error of $5-10 \%$ is $0.5-1.0 \mathrm{ka}$. This is an experimental reason why our perception of abrupt change for older deposits is often different from that applied to modern sediments.

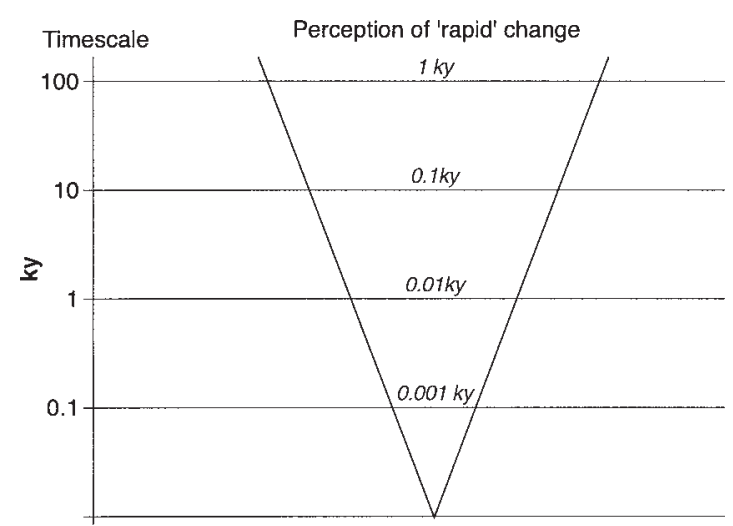

Figure 4 - Perception of 'rapid' change is often related to the timescale of enquiry. $1 \mathrm{k}$ yr appears as a period of rapid change in the context of a glacial cycle, but over the $10 \mathrm{k} \mathrm{yr}$ of Holocene time a century of rapid change is commonly sought. Over recorded time of $100 \mathrm{yr}$, a rapid change would be seen as taking place within a single year, perhaps over weeks or months.

- The importance of 'landscape sensitivity'

Connected to these problems are questions about 'landscape sensitivity' (THOMAS 2001). This is because high-resolution studies of sedimentary sections or cores will usually assume the following:

1. That the record is complete and contains no episodes of erosion (unconformities)

2. That each depositional event reflects accurately the magnitude of every climatic event (intensity, duration)

3. That sediment at each stage comes from the same source area(s)

4. That the source area(s) exhibit equal sensitivity to erosion throughout the period.

But none of these conditions can be guaranteed because:

1. The process of sedimentation itself may disturb underlying deposits

2. Many factors can influence the flow magnitude at the site during deposition, including preevent catchment conditions, such as regolith saturation, and status of vegetation cover

3. Potential source areas for sediment within a catchment are many, and unless the source-tosink pathway is short and unambiguous, may change from one event to the next, partly as a 
consequence of spatial variability in rainfall intensity across the catchment

4. Underlying these ambiguities is the variability in space and time of the sensitivity of all source areas to erosion.

Sensitivity can vary spatially because of inherent landscape patterns (rocks, soils, altitude, slopes, plant cover) and over time because of factors such as sediment exhaustion, active weathering, soil profile development, and increasing (or decreasing) biodiversity of the land cover. Perturbations in the external environment, in rainfall patterns and intensities for example, are superimposed on the inherent spatial variability of the landscape in ways that complicate further the resultant patterns of landscape response in terms of erosion and sedimentation (see PHILLIPS 1999). There may be a stochastic element in the spatial distribution of high intensity rainfalls, while there may also be systematic changes in the frequency of high magnitude events over periods of $10^{2}-10^{3} \mathrm{yr}$.

Combinations of these factors can lead to apparent inconsistencies in landscape response, between adjacent catchments or hillslopes for example, and may mean that isolated studies do not reveal a full history of environmental and landscape change at a regional level. The major landslides of eastern Zambia are interesting because they affect all hills of similar geology in a region of $10^{2} \mathrm{~km}^{2}$ and record events of considerable rarity on a Quaternary timescale $\left(10^{5} \mathrm{yr}\right)$. The landscape has not been sensitive to major slope failure over the last $200 \mathrm{k}$ yr. On the other hand, sediment has been shed from these same slopes frequenly throughout the Last Glacial Cycle and has accumulated as colluvium and alluvium forming a distinct piedmont slope underlain by fine sediment interspersed with discontinuous beds of quartzite cobbles. Sensitivity has, therefore, to be interpreted in terms of major process domains: from channel response to slope erosion and failure.

The concentration of landscape change within comparatively short periods of intense activity, as at Bananal in southeastern Brazil or in the formation of fans in NE Queensland, poses interesting questions for geomorphology. One such question concerns the magnitude/frequency relationships of formative events needed to accomplish the observed changes. In the 'wet tropics' of northern Queensland failure of the monsoon during the LGM possibly led to loss of stream power and also forest protection of slopes. This led to copious sedimentation along the coastal piedmont plain (THOMAS et al 2001). In Eastern Zambia the climate is drier and sediment production may have accompanied abrupt warming episodes throughout the Last Glacial Cycle (THOMAS \& MURRAY 2001).

There is a need to develop regional models describing landscape sensitivity and response to Quaternary and contemporary climate changes. These will come about through increased efforts to understand the Quaternary record of slope activity and the formation and duration of sediment stores in the landscape. The coupling of such sediment stores to stream channels is also an essential component of such models but this lies beyond the scope of the present discussion.

\section{REFERENCES}

AB'SÁBER, A.N. 1982. The paleoclimate and paleoecology of Brazilian Amazonia. In: G.T.Prance (ed.) Biological Diversification in the Tropics, New York, Columbia, p. 1-59.

BAKKER, J.P. 1957. Quelques aspects du problème des sediments correlatives en climat tropical humide. Zeitschrift für Geomorphologie, N.F. 1:3-43.

BEHLING, H. 1997. Late Quaternary vegetation, climate and fire history from the tropical mountain region of Morro de Itapeva, SE Brazil. Palaeogeography, Palaeoclimatology and Palaeoecology, 129: 407-422.

BLANC-VALLERON, M-M.; THIRY, M. 1997. Clay minerals, palaeoweathering, palaeolandscapes and climatic sequences: the Paleogene continental deposits in France. In: H. Paquet \& N. Clauer (eds.) Soils and Sediments Mineralogy and Geochemistry, Berlin, Springer, p.223-247.

BOULET, R.; LUCAS, Y.; FRITSCH, E.; PAQUET, H. 1997. Geochemical processes in tropical landscapes: role of the soil covers. In: $\mathrm{H}$. Paquet \& N. Clauer (eds.) Soils and Sediments - Mineralogy and Geochemistry, Berlin, Springer, p.67-96.

BRABANT, P. 1987. La répartition des podzols à Kalimantan. In: D. Righi \& A. Chauvel (eds.) Podzols et Podzolisation, Paris, AFES \& INRA, p.13-24. 
CHAUVEL, A. 1977. Recherches sur la transformation des sols ferrallitiques dans la zone tropicale à saisons contrastées. Paris, ORSTOM, (Travaux et Documents 62), $532 \mathrm{p}$.

; LUCAS, Y; BOULET, R. 1987. On the genesis of the soil mantle of the region of Manaus, Central Amazonia, Brazil. Experientia, 43: 234241.

COELHO NETTO, A.L. 1999. Catastrophic landscape evolution in a humid region (SE Brazil): inheritances from tectonic, climatic and land use induced changes. Geogr. Fis. Dinam. Quat. Suppl., 111(3): 21-48.

DE MEIS, M.R.M.; MOURA, J.R. 1984. Upper Quaternary sedimentation and hillslope evolution: southeastern Brazilian plateau. American Journal of Science, 284: 241-254.

; MACHADO, M.B. 1978. A morfologia de rampas e terraços no Planalto do Sudeste do Brasil. Finisterra, 13: 201-219.

; MONTEIRO,A.M.F. 1979. Upper Quaternary "rampas": Doce River valley, Southeastern Brazilian plateau. Zeitschrift für Geomorphologie, N.F., 23: 132-151.

DUBROEUCQ, D.; BLANCANEAUX, P. 1987. Les podzols du haut Rio Negro, région de Maroa, Venezuela. Environement et rélations lithologiques. In: D. Righi \& A. Chauvel (eds.) Podzols et Podzolisation, C. R. Table Ronde Internationale, Association Française pour l'Étude du Sol, ORSTOM/INRA, p. 3752.

; VOLKOFF, B. 1998. From oxisols to spodosols and histosols: evolution of soil mantles in the Rio Negro basin (Amazonia). Catena, 32: 245280.

ERHART, H. 1955. Biostasie et rhexistasie: esquisse d'une théorie sur le rôle de la pédogenèse en tant que phénomène géologique. $C$. R. Acad. Sc. Paris, 241: 1218-1220.

ERIKSSON, M.G;; OLLEY J.O.; PAYTON, R.W. 1999. Late Pleistocene colluvial deposits in central Tanzania: erosional response to climatic change ? GFF, 121: 198-201.
FAIRBRIDGE, R.W.; FINKL, C.W. JR. 1980. Cratonic erosional unconformities and peneplains. Journal of Geology, 88: 69-86.

1984. Tropical stone lines and podzolised sand plains as palaeoclimatic indicators for weathered cratons. Quaternary Science Reviews, 3: 41-72.

FINNEY, B.P.; JOHNSON, T.C. 1991. Sedimentation in Lake Malawi (East Africa) during the past 10 000 years: a continuous palaeoclimatic record from the southern tropics. Palaeogeography, Palaeoclimatology and Palaeoecology, 85: 351-356.

GASSE, F. 2000. Hydrological changes in the African tropics since the Last Glacial Maximum. Quaternary Science Reviews, 19: 189-211.

GOUDIE, A.S.; BULL, P.A. 1984. Slope processes and colluvium deposition in Swaziland: an SEM analysis. Earth Surface Processes and Landforms, 9: 289-299.

HEYLIGERS, P.C. 1963. Vegetation and soil of a white-sand savanna in Suriname. Verhandelingen der koninklijke Nederlandse Akademie van Wetenschappen, AFD Natuurkunde. N.V. Noord-Hollandshce Uitgevers Maatschappij, Amsterdam, p.148.

JOSHI, V.U.; KALE, V.S. 1997. Colluvial deposits in NW Deccan, India: their significance in the interpretation of late Quaternary history. Journal of Quaternary Science, 12: 391-403.

KADOMURA, H. 1995. Palaeoecological and palaeohydrological changes in the humid tropics during the last 20,000 years, with reference to equatorial Africa. In: K.J. Gregory, L. Starkel \& V.R. Baker (eds.) Global Continental Palaeohydrology, Chichester, John Wiley, p.177-202.

KERSHAW, A.P. 1978. Record of last interglacialglacial cycle from northeastern Queensland. Nature, 272: 159-161.

LEDRU, M-P.; BERTAUX, J.; SIFEDDINE, A.; SUGUIO, K. 1998. Absence of Last Glacial Maximum records in lowland tropical forests. Quaternary Research, 49: 233-237. 
LUCAS, Y.; BOULET, R.; CHAUVEL, A. 1988. Intervention simultanée des phénomènes d'enforcement vertical et de transformation latérale dans la mise en place de systèmes sols ferrallitiques-podzols de l'Amazonie Brésilienne. C.R. Acad. Sc,. Paris, t. 306, Serie II, 1395-1400.

MEADOWS, M.E. 1983. Past and present environments of the Nyika Plateau, Malawi. Palaeoecology of Africa, 16: 353-390.

1985. Dambos and environmental change in Malawi, central Africa. In: M.F. Thomas \& A.S. Goudie (eds.) Dambos: Small Channelless Valleys in the Tropics. Zeitschrift für Geomorphologie Supplem., 52: 47-169.

MICHEL, P. 1973. Les Bassins des fleuves Sénégal et Gambie - étude géomorphologique. ORSTOM, 752 p. (Memoires 63).

MILLOT, G. 1964. Géologie des Argiles. Paris, Masson, 499 p. (Engl. transl. W.R. Farrand \& H. Paquet, Geology of Clays, 1970, London, Chapman \& Hall, 429 p.).

MODENESI, M.C. 1983. Weathering and morphogenesis in a tropical plateau. Catena, 10: 237-251.

1988. Quaternary mass movements in a tropical plateau (Campos do Jordão, São Paulo, Brazil). Zeitschrift für Geomorphologie N.F., 32: 425-440.

MODENESI-GAUTTIERI, M.C. 2000. Hillslope deposits and the Quaternary evolution of the altos campos - Serra da Mantiqueira, from Campos do Jordão to the Itatiaia

Massif. Revista Brasileira de Geociências, 30 (3): 504-510.

MOSS, R.P. 1965. Slope development and soil morphology in a part of southwest Nigeria. Journal of Soil Science, 16: 192-209.

MOSS, P.T.; KERSHAW, P.A. 2000. The last glacial cycle from the humid tropics of northeastern Australia: comparison of a terrestrial and a marine record. Palaeogeography, Palaeoclimatology, Palaeoecology, 155: 155176.
MOURA, J.R.S.; SILVA, T.M., MELLO, C.L.; PEIXOTO, M.N.O.; SANTOS, A.A.M.; ESTEVES, A.A. 1989. Roteiro geomorfológicoestratigráfico da região de Bananal (São Paulo). In: ABEQUA, CONGRESSO DA ASSOCIAÇAO BRASILEIRADE ESTUDOSDO QUATERNÁRIO, 2, Rio de Janeiro, Publicação Especial, 2, $26 \mathrm{p}$.

NOTT, J.; THOMAS, M.F.; PRICE, D.M. 2001. Alluvial fans, landslides and Late Quaternary climatic change in the wet tropics of northeast Queensland. Australian Journal of Earth Sciences, 48.

PHILLIPS, J. D. 1999. Earth Surface Systems, Oxford, Blackwell.

RENEAU, S.L.; DIETRICH, W.E.; DORN, R.I.; BERGER, C.R.; RUBIN, M. 1986. Geomorphic and paleoclimatic implications of latest Pleistocene radiocarbon dates from colluviummantle hollows, California. Geology, 14: 655-658.

RUNGE, J. 1992. Geomorphological observations concerning palaeoenvironmental conditions in eastern Zaire. Zeitschrift für Geomorphologie Supplem., 91: 109-122.

1996. Palaeoenvironmental interpretation of geomorphological and pedological studies in the rain forest "core areas" of eastern Zaire (central Africa). South African Geographical Journal, 78: 91-97.

2001. On the age of stone-lines and hillwash sediments in the eastern Congo basin palaeoenvironmental implications. Palaeoecology of Africa, 27: 1-10.

SCHOLTZ, C.A.; FINNEY, B.P. 1994. Late Quaternary sequence stratigraphy of Lake Malawi (Nyasa), Africa. Sedimentology, 41: 163-179.

SHRODER, Jr. J.F. 1976. Mass movements on the Nyika Plateau, Malawi. Zeitschrift für Geomorphologie, N.F., 20: 56-77.

SØRENSEN, R.; MURRAY, A.S.; KAAYA, A.K.; KILASARA, M.; 2001.Stratigraphy and formation of late Pleistocene colluvial apron in Morogoro district, central Tanzania. Palaeoecology of Africa, 27: 95-116. 
THOMAS, M.F. 1994. Geomorphology in the Tropics. Chichester, John Wiley \& Sons, 460 p.

1998. Late Quaternary landscape instability in the humid and sub-humid tropics. In: G. Benito, V. R. Baker \& K.J. Gregory (eds.) Palaeohydrology and Environmental Change, Chichester, John Wiley \& Sons, p. 247-258.

1999. Evidence for high-energy landforming events on the central African plateau: eastern Province Zambia. Zeitschrift für Geomorphologie, N.F., 43: 273-297.

2001. Landscape sensitivity in time and space - an introduction. Catena (Special Issue, M.F. Thomas \& I.A. Simpson (eds.). Landscape Sensitivity: Principles and Applications in Northern Cool Temperate Environments), 42: 83-98.

; MURRAY, A.S. 2001. On the age and significance of Quaternary colluvium in eastern Zambia. Palaeoecology of Africa, 27: 117-133.

; THORP, M.B. 1985. Environmental change and episodic etchplanation in the humid tropics of Sierra Leone: the Koidu etchplain. In: I. Douglas \& T. Spencer (eds.) Environmental Change and Tropical Geomorphology, London, Allen \& Unwin, p. 239-267.

NOTT, J.M.,\& PRICE, D.M. 2001. Late Quaternary stream sedimentation in the humid tropics: a review with new data from NE Queensland, Australia. Geomorphology, 39: 5368.

; THORP, MB; MCALISTER, J. 1999. Equatorial weathering, landform development and the formation of white sands in Northwestern Kalimantan, Indonesia. Catena, 36: 205-232.

THORP, M.B.; THOMAS, M.F.; MARTIN, T.; WHALLEY, W.B. 1990. Late Pleistocene sedimentation and landform development in western Kalimanatan (Indonesian Borneo). Geologie en Mijnbouw, 69: 133-150.

TRICART, J. 1959. Observations sure le façonnement des rapides des rivières intertropicales. Bulletin Séction Géographique, Comité Travaux Historique et Scientifique, 68: 333343.

CAILLEUX, A. 1965. Introduction à la Géomorphologie Climatique. Paris, SEDES.

TRUCKENTBRODT, W.; KOTSCHOUBEY, B.; SCHELLMANN, W. 1991. Composition and origins of the clay cover on north Brazilian laterites. Geologische Rundschau, 80: 591-610.

WATSON, A.; PRICE-WILLIAMS D.; GOUDIE, A.S. 1983. Palaeoenvironmental interpretation of colluvial sediments and palaeosols of the Late Pleistocene hypothermal in southern Africa. Palaeogeography, Palaeoclimatology and Paleoecology, 45: 225-250.

Address of the author:

Michael F. Thomas, Department of Environmental Sciences, University of Stirling, Stirling, FK9 4LA Scotland, UK.E-mail:m.f.thomas@stir.ac.uk 